\title{
ВИЗНАЧЕННЯ ФІЗИКО-МЕХАНІЧНИХ ВЛАСТИВОСТЕЙ МЕТАЛЕВИХ ПОРОШКІВ ДЛЯ НАПЛАВЛЕННЯ
}

В даний час з'являється безліч порошкових матеріалів, що відрізняються по складу, опис процесу деформації, яких вимагає проведення додаткових експериментів. Відзначене робить доцільним створення експериментальної установки та методики для найбільш точного і по можливості швидкого визначення фізико-механічних властивостей нових порошкових композицій.

Для опису напружено-деформованого стану при обробці тиском порошкових матеріалів необхідним є знання залежностей між напруженнями і щільністю порошкового середовища, тобто знання умови пластичності.

Такі феноменологічні моделі механіки грунтів як моделі Кулона-Мора, ДрукераПрагера, Cam-Clay i CAP [1-5], широко використовуються для опису властивостей порошків при обробці тиском. Застосування таких моделей поведінки порошкових матеріалів полегшує використання методів скінченних елементів.

Метою роботи є експериментальне визначення фізико-механічних властивостей металевих порошків, що використовуються в електродах для наплавлення поверхонь, а також уточнення залежностей для їх опису.

Найбільше поширення при аналітичному математичному моделюванні процесів обробки порошкових матеріалів одержала еліптична умова пластичності, що поєднує високу точність опису при відносно простому експериментальному визначенні фізико-механічних властивостей порошкових матеріалів [6]:

$$
\mathrm{f}=\frac{1}{2} \cdot\left[\left(\sigma_{1}-\sigma_{2}\right)^{2}+\left(\sigma_{2}-\sigma_{3}\right)^{2}+\left(\sigma_{3}-\sigma_{1}\right)^{2}\right]+\alpha \cdot\left(\sigma_{1}+\sigma_{2}+\sigma_{3}\right)^{2}-\beta \cdot \sigma_{\mathrm{s}}^{2}=0,
$$

де $\sigma_{1}, \sigma_{2}, \sigma_{3}$ - головні напруження, що діють на порошкове середовище при деформації; $\alpha, \beta$ - коефіцієнти, що враховують специфіку деформації саме порошкового середовища; $\sigma_{\mathrm{s}}-$ значення границі текучості твердої фази порошкової композиції даного складу.

Одними з основних характеристик, що використовуються при розрахунку різних технологічних процесів обробки порошкових матеріалів, є функціональні зв'язки коефіцієнтів умови пластичності (1) і відносної щільності $\gamma$, тобто функціональні зв'язки $\alpha(\gamma), \beta(\gamma)$ и $\sigma_{s}(\gamma)$, котрі визначаються експериментальним шляхом. Знання кількісних оцінок зазначених вище функціональних зв'язків є необхідним для розрахунку як локальних, так і інтегральних характеристик напружено-деформованого стану, a, отже, i для розрахунку всього комплексу основних технологічних параметрів процесів обробки тиском.

Для експериментальних досліджень була використана установка, загальний вид якої представлений на рис. 1.

Пристрій працює наступним чином: під дією пресувального механізму верхній пуансон діє на порошкову композицію відомою силою Ү, під дією якої відбувається деформація порошкового матеріалу, яка, в свою чергу, викликає радіальну силу $\mathrm{F}$, що вимірюється за допомогою месдоз. Безпосередньо осьові контактні напруження $p_{i}$ визначають в цьому випадку за формулою: 


$$
\mathrm{p}_{\mathrm{i}}=4 \mathrm{Y}_{\mathrm{i}} / \pi\left(\mathrm{D}_{\mathrm{M}}^{2}-\mathrm{D}_{\mathrm{c}}^{2}\right)
$$

де $\mathrm{D}_{\mathrm{M}}, \mathrm{D}_{\mathrm{c}}$ - діаметри матриці та центруючого стрижня відповідно.

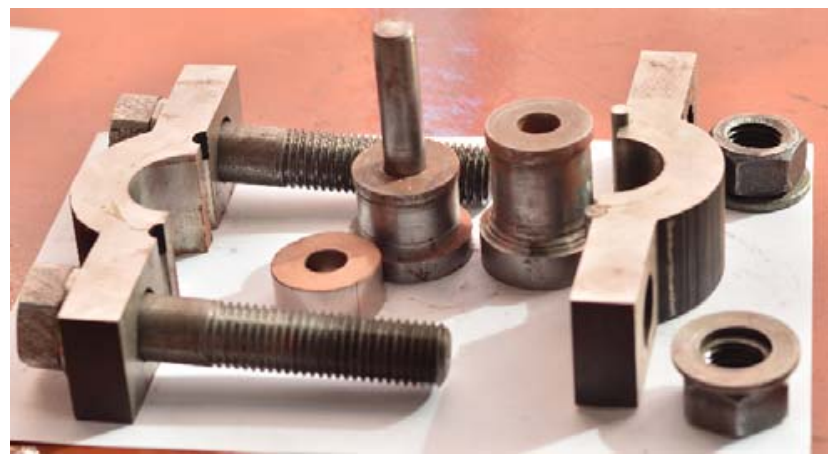

a

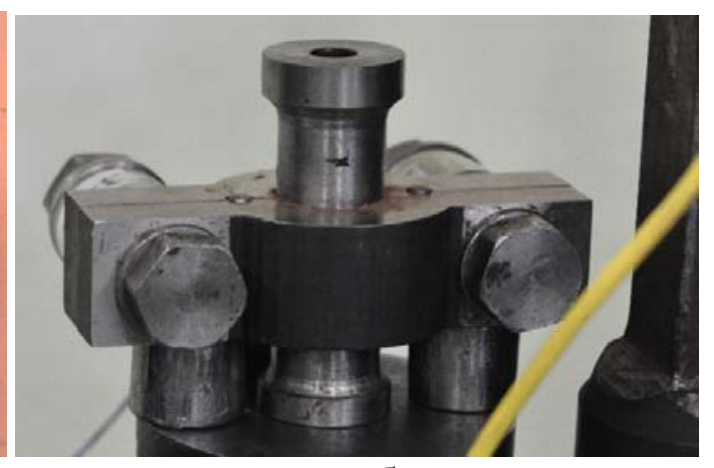

6

Рис. 1. Загальний вигляд експериментальної установки для визначення фізикомеханічних властивостей порошкових матеріалів:

а - складові установки; б - вид в зборі

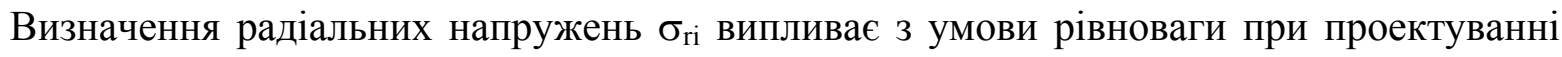
всіх сил на горизонтальну площину:

$$
\mathrm{F}_{\mathrm{i}}=\int_{0}^{\pi} \sigma_{\mathrm{ri}} \cdot \sin \alpha \cdot \mathrm{R} d \alpha \cdot \mathrm{h}_{\mathrm{i}}=\left.\sigma_{\mathrm{ri}} \cdot(-\cos \alpha) \cdot \mathrm{R}\right|_{0} ^{180} \cdot \mathrm{h}_{\mathrm{i}}=2 \cdot \sigma_{\mathrm{ri}} \cdot \mathrm{R} \cdot \mathrm{h}_{\mathrm{i}}=\sigma_{\mathrm{ri}} \cdot \mathrm{D}_{\mathrm{M}} \cdot \mathrm{h}_{\mathrm{i}},
$$

звідки з урахуванням відомого виміряного значення $\mathrm{F}_{\mathrm{i}}$ величина $\sigma_{\mathrm{ri}}$ відповідає:

$$
\sigma_{\mathrm{ri}}=\frac{\mathrm{F}_{\mathrm{i}}}{\mathrm{h}_{\mathrm{i}} \mathrm{D}_{\mathrm{M}}}
$$

де $\mathrm{h}_{\mathrm{i}}$ - висота заготовки.

Визначення коефіцієнтів $\alpha_{\mathrm{i}}, \beta_{\mathrm{i}}$ i $\sigma_{\mathrm{s}}$ здійснюється за формулами [6]:

$$
\alpha_{i}=\frac{1-\sigma_{\mathrm{ri}} / \mathrm{p}_{\mathrm{i}}}{2\left(1+2 \sigma_{\mathrm{ri}} / \mathrm{p}_{\mathrm{i}}\right)} ; \beta_{\mathrm{i}} \sigma_{\mathrm{s}}^{2}=\frac{9 \alpha_{\mathrm{i}}}{1+4 \alpha_{\mathrm{i}}} \mathrm{p}_{\mathrm{i}}^{2}
$$

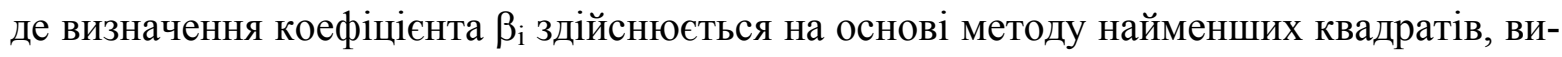
ходячи з припущення про сталість значення $\sigma_{\mathrm{s}}$.

Тарування месдоз для вимірювання осьової та радіальної складових сили пресування (рис. 2, а) здійснювали на окремому гідравлічному пресі шляхом імітаційного навантаження силою відомої величини (рис. 2, б).

Для визначення всіх компонент напружено-деформованого стану при пресуванні порошкової композиції необхідним є знання її деформації. При проведенні експерименту для визначення поточного положення пуансонів було використано датчик лінійних переміщень BALLUFF BTL5-A11-MO200-P-S32, корпус котрого був жорстко закріплений до станини, а магнітний датчик - до нижнього пуансону. Зазор між корпусом і магнітним датчиком не перевищував 20 мм. Тарування здійснювали за допомогою індикатору годинникового типу (рис. 3). 


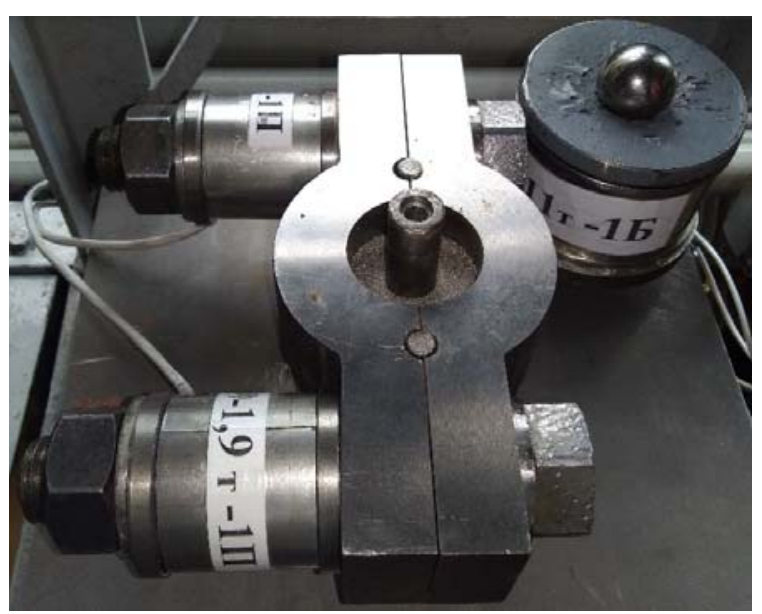

$\mathrm{a}$

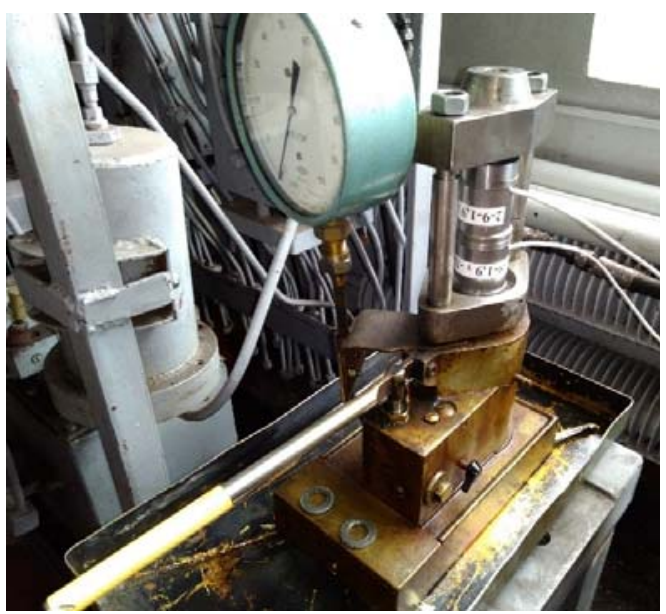

б

Рис. 2. Загальний вид месдоз для вимірювання осьової і радіальної складових сили пресування (а) та їхнього тарування на гідравлічному пресі (б)

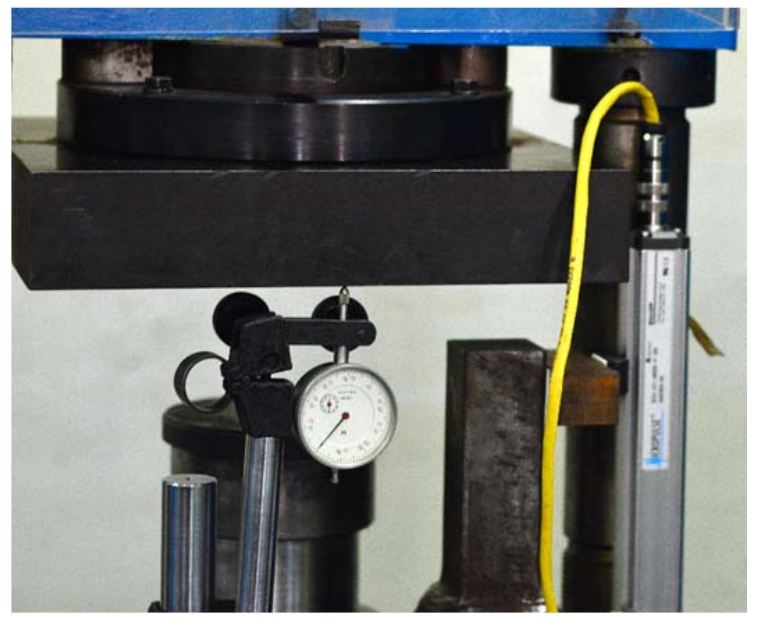

Рис. 3. Схема розташування датчика лінійних переміщень BALLUFF BTL5-A11-MO200-P-S32 та індикатору годинникового типу при таруванні

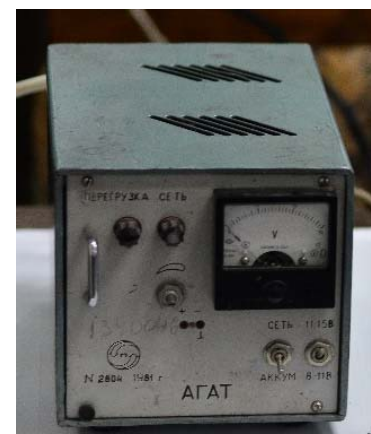

a

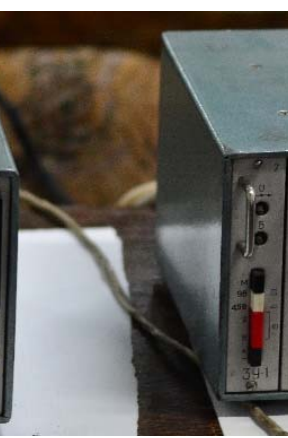

(1)

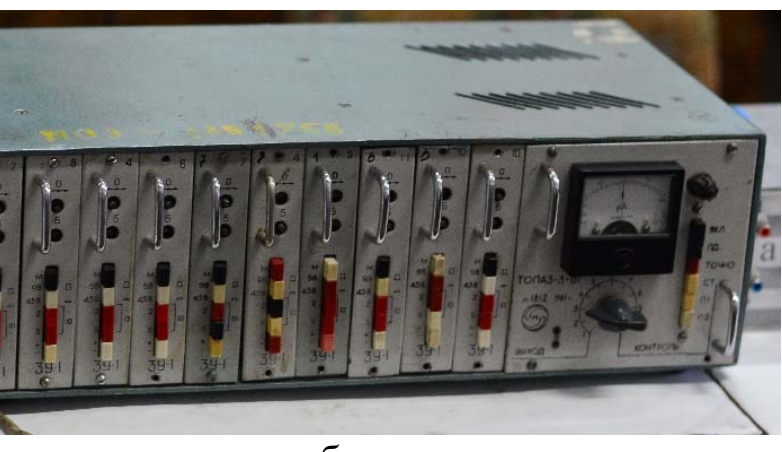

б

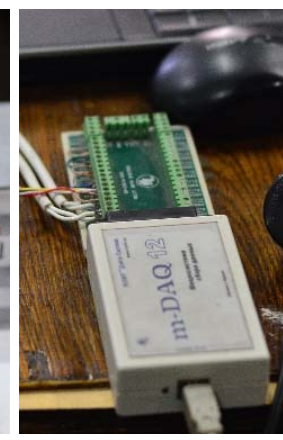

B

Рис. 4. Загальний вид вимірювальної апаратури:

a - блок живлення АГАТ; б - тензопідсилювач TOПАЗ 3-01; в - АЦП m-DAQ 12

При проведенні експериментальних досліджень дула використана наступна вимірювальна апаратура (рис. 4): блок живлення АГАТ для подання живлення на тензодатчики (рис. 4, а); тензопідсилювач ТОПАЗ 3-01 для збільшення сигналу від месдоз (рис. 4, б); аналого-цифровий перетворювач m-DAQ 12 (рис. 4, в) для перетворення аналогового сигналу від тензодатчиків у цифровий для обробки на ЕОМ; ноутбук для реєстрації сигналів.

В ході експерименту було здійснено визначення механічних властивостей порошків для наплавлення. Технологічна сутність експерименту полягала в пресуванні відповідної 
порошкової композиції в закритій матриці при різних, варійованих за величиною, значеннях сили $\mathrm{Y}_{\mathrm{i}}$. При цьому саме пресування виконували на гідравлічному пресі зусиллям 500 кН кафедри ОМТ (ДДМА, м. Краматорськ) (рис. 5).

Для визначення механічних властивостей порошку одного складу досить одного експерименту, так як використання датчика лінійних переміщень дозволило визначити поточну висоту заготовки, відповідну поточному значенню сили пресування $\mathrm{Y}_{\mathrm{i}}$, тобто одним експериментом замінювалося ціла їх серія. Тарування месдози для вимірювання радіальної складової сили пресування виробляли на окремому гідравлічному пресі шляхом імітаційного навантаження силою відомої величини.
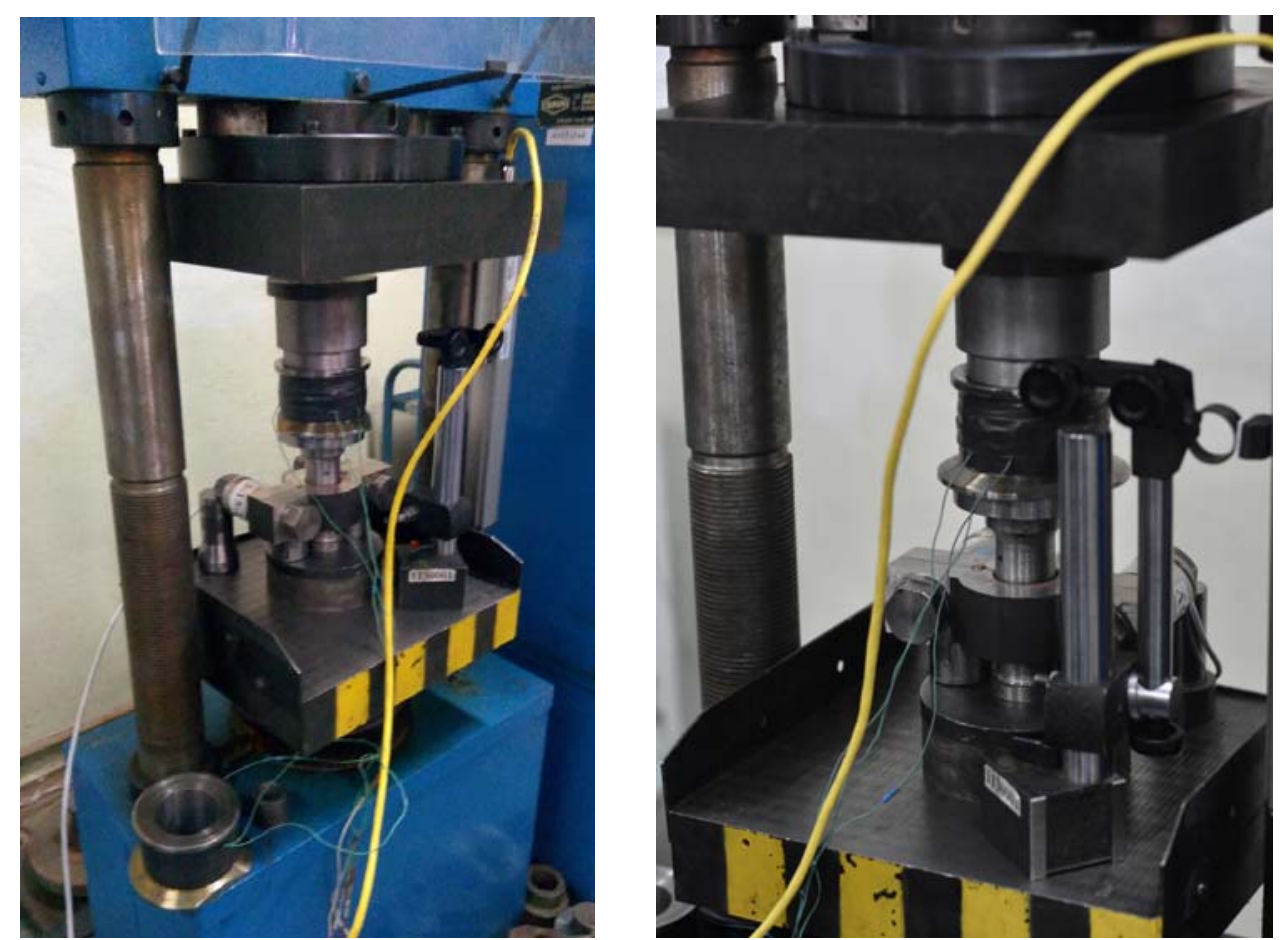

Рис. 5. Загальні вигляди експериментальної установки, встановленої на столі гідравлічного пресу зусиллям 500 кН

3 метою безпосереднього визначення поточної щільності зразок зважували відразу після пресування на лабораторних вагах з похибкою до 0,01 г, а одночасно 3 цим вимір кінцевої висоти виробляли за допомогою інструментального мікрометра з похибкою, що не перевищує 0,01 мм.

3 урахуванням відомих значень маси заготовки $\mathrm{M}$ і геометричних характеристик $\mathrm{D}_{\mathrm{M}}$, $\mathrm{d}_{\mathrm{c}}, \mathrm{h}_{\mathrm{i}}$ величину щільності $\rho_{\mathrm{i}}$ в кожному окремому випадку визначали 3 очевидного співвідношення:

$$
\rho_{i}=\frac{4 M}{\pi\left(D_{M}^{2}-D_{c}^{2}\right) h_{i}},
$$

де $h_{\mathrm{i}}-$ висота заготовки.

Тут варто зазначити на те, що для визначення відносного показника щільності $\gamma_{i}=\rho_{i} / \rho_{M}$, крім власне визначуваного емпіричного значення щільності $\rho_{\mathrm{i}}$, необхідною $є$ і кількісна оцінка щільності досліджуваної композиції в іiї монолітному стані $\rho_{\mathrm{M}}$. Величина $\rho_{\mathrm{м}}$ для композиції, що містить $\mathrm{n}$ компонентів, у свою чергу, може бути визначена чисто аналітично з наступної формули: Розділимо ліву і праву частини рівняння на масу моноліту $\mathrm{M}_{\mathrm{M}}$ : 


$$
\rho_{M}=1 / \sum_{j=1}^{n} m_{j} / \rho_{M j} .
$$

де j - порядковий номер кожної окремої складової досліджуваної порошкової композиції масою т та щільністю в монолітному стані $\rho_{\mathrm{M}}$.

Як приклад результатів проведеного дослідження в табл. 1 дана кількісна, а на рис. 6-рис. 8 - графічна інтерпретація залежностей напружень і коефіцієнтів $\alpha(\gamma)$ і $\beta(\gamma)$, отримані при пресуванні порошку для наплавлення наступного складу: хром - 50\%, алюміній $-15 \%$, реліт $-35 \%$.

Таблиця 1

Експериментальні значення компонент напружено-деформованого стану,

а також розрахункові значення коефіцієнтів $\alpha$ і $\beta$

\begin{tabular}{|c|c|c|c|c|c|c|c|c|c|c|}
\hline № $3 / \Pi$ & $\begin{array}{c}\text { Сила } \\
\text { пресу- } \\
\text { вання, } \\
\text { кН } \\
\end{array}$ & $\begin{array}{c}\text { Радіа- } \\
\text { льна } \\
\text { сила, кН }\end{array}$ & $\begin{array}{c}\text { Висота } \\
\text { заготов- } \\
\text { ки, мм }\end{array}$ & $\mid \begin{array}{c}\text { Обтис- } \\
\text { нення, } \\
\%\end{array}$ & $\begin{array}{c}\text { Осьові } \\
\text { напру- } \\
\text { ження, } \\
\text { МПа } \\
\end{array}$ & \begin{tabular}{|c|} 
Радіальні \\
напру- \\
ження, \\
МПа
\end{tabular} & 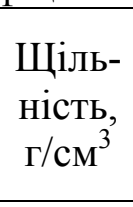 & $\begin{array}{c}\text { Від- } \\
\text { носна } \\
\text { щіль- } \\
\text { ність } \\
\end{array}$ & $\alpha$ & $\beta$ \\
\hline 1 & 0.00 & 0.11 & 38.03 & 0 & 0.0 & 0.1 & 2.17 & 0.23 & 0.500 & 0 \\
\hline 2 & 4.32 & 0.97 & 30.71 & 19.2 & 4.1 & 0.8 & 2.69 & 0.28 & 0.292 & $1.538 \mathrm{E}-05$ \\
\hline 3 & 5.45 & 1.36 & 30.02 & 21.1 & 5.2 & 1.1 & 2.75 & 0.29 & 0.272 & $2.373 \mathrm{E}-05$ \\
\hline 4 & 5.45 & 1.39 & 29.90 & 21.4 & 5.2 & 1.2 & 2.76 & 0.29 & 0.269 & 2.359E-05 \\
\hline 5 & 5.45 & 1.39 & 29.82 & 21.6 & 5.2 & 1.2 & 2.77 & 0.29 & 0.268 & $2.358 \mathrm{E}-05$ \\
\hline 6 & 7.27 & 1.56 & 29.67 & 22.0 & 6.9 & 1.3 & 2.78 & 0.29 & 0.294 & $4.372 \mathrm{E}-05$ \\
\hline 7 & 11.36 & 2.42 & 29.20 & 23.2 & 10.8 & 2.1 & 2.83 & 0.30 & 0.293 & 0.00011 \\
\hline 8 & 20.11 & 4.95 & 28.10 & 26.1 & 19.1 & 4.4 & 2.94 & 0.31 & 0.264 & 0.00032 \\
\hline 9 & 28.74 & 7.83 & 27.15 & 28.6 & 27.3 & 7.2 & 3.04 & 0.32 & 0.242 & 0.00062 \\
\hline 10 & 43.51 & 12.60 & 25.90 & 31.9 & 41.4 & 12.1 & 3.19 & 0.34 & 0.223 & 0.00137 \\
\hline 11 & 58.06 & 16.87 & 24.67 & 35.1 & 55.2 & 17.0 & 3.35 & 0.35 & 0.214 & 0.00238 \\
\hline 12 & 73.81 & 21.47 & 23.53 & 38.1 & 70.1 & 22.7 & 3.51 & 0.37 & 0.205 & 0.00376 \\
\hline 13 & 83.96 & 24.15 & 22.91 & 39.7 & 79.8 & 26.3 & 3.60 & 0.38 & 0.202 & 0.00483 \\
\hline 14 & 96.23 & 27.23 & 22.20 & 41.6 & 91.5 & 30.5 & 3.72 & 0.39 & 0.200 & 0.00629 \\
\hline 15 & 115.89 & 31.78 & 21.20 & 44.2 & 110.1 & 37.3 & 3.90 & 0.41 & 0.197 & 0.00906 \\
\hline 16 & 127.13 & 34.66 & 20.60 & 45.8 & 120.8 & 41.9 & 4.01 & 0.42 & 0.193 & 0.01077 \\
\hline
\end{tabular}

3 аналізу отриманих результатів є очевидним, що зі збільшенням обтиснення осьові і радіальні напруження зростають (див. рис. 6), але їх відношення одне до одного носить нелінійний характер (див. рис. 7). Також складний характер носить залежність коефіцієнтів $\alpha$ i $\beta$ умови пластичності від відносної щільності (див. рис. 8). В міру збільшення відносної щільності $\gamma$ значення коефіцієнта $\alpha$ знижуються практично нелінійно.

Значення коефіцієнтів $\alpha$ і $\beta$, відповідно до рекомендацій роботи [6], можуть бути описані як:

$$
\alpha=\mathrm{a}(1-\gamma)^{\mathrm{m}} ; \beta=\gamma^{2 \mathrm{n}}
$$

де $\mathrm{a}, \mathrm{m}, \mathrm{n}$ - постійні для кожного конкретного складу значення коефіцієнтів, що характеризують інтенсивність зміни $\alpha$ і $\beta$ в залежності від зміни показника відносної щільності $\gamma$. 


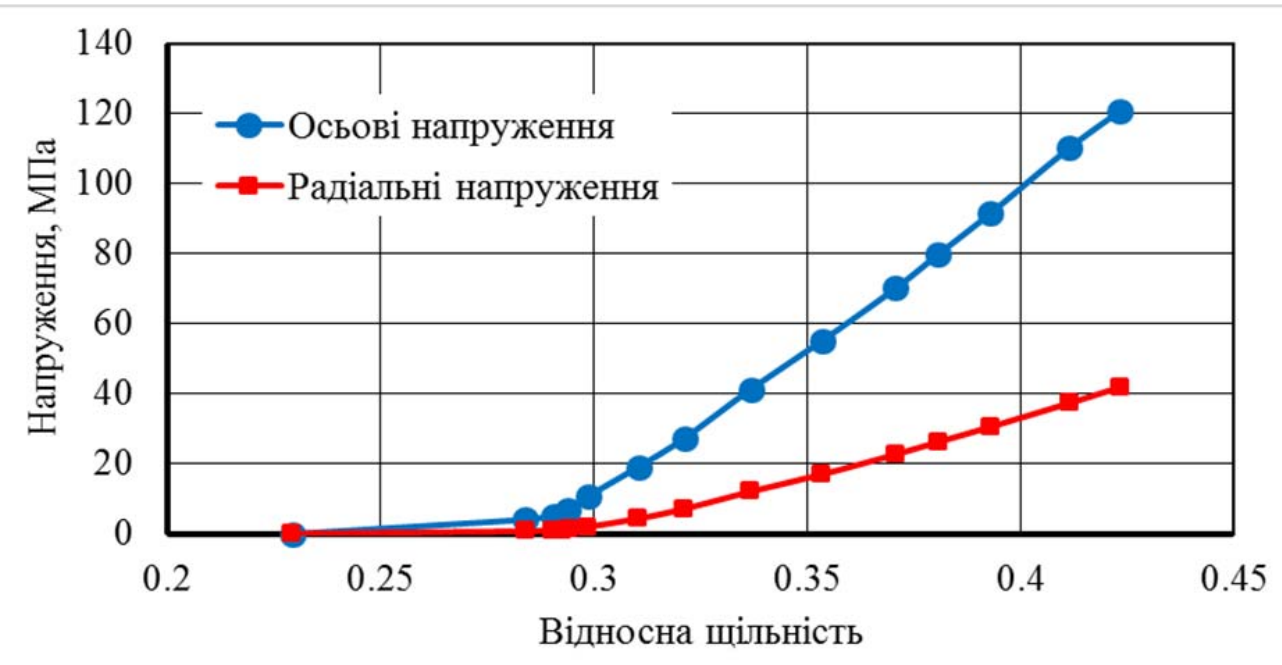

Рис. 6. Розподіл осьових і радіальних напружень в залежності від відносної щільності при пресуванні порошку в закритій матриці

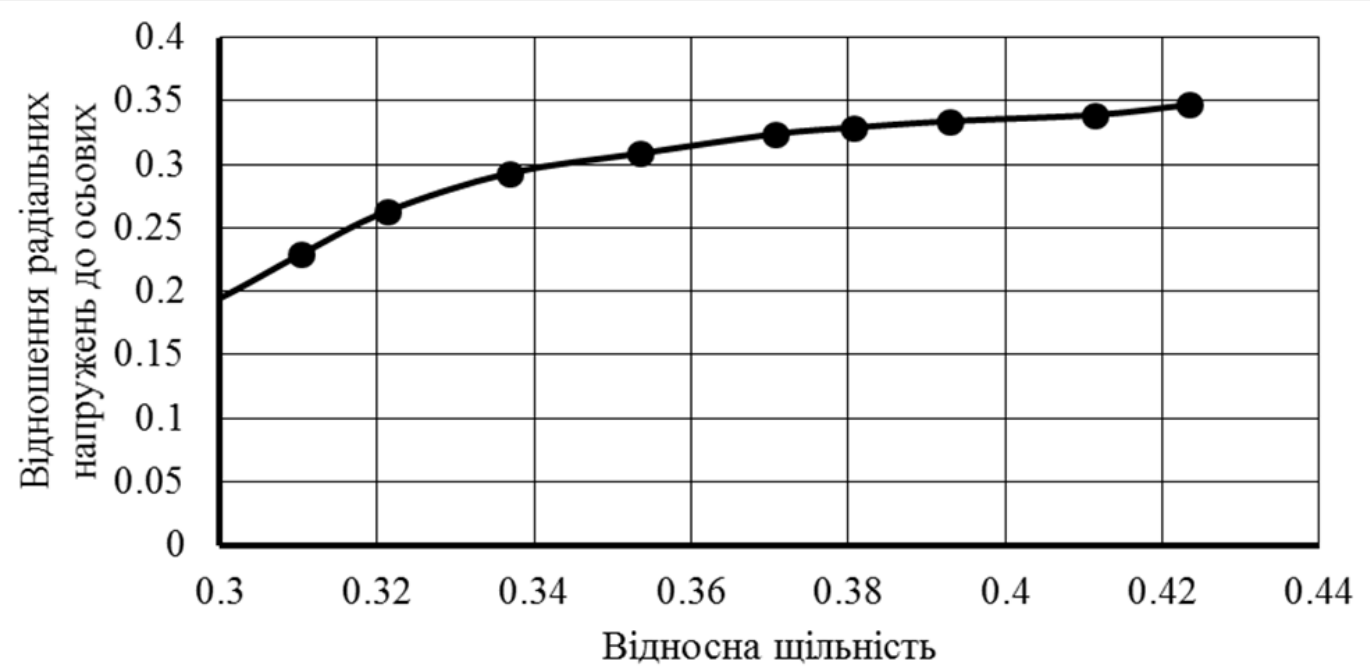

Рис. 7. Розподіл відношення радіальних напружень до осьових в залежності від обтиснення при пресуванні порошку в закритій матриці

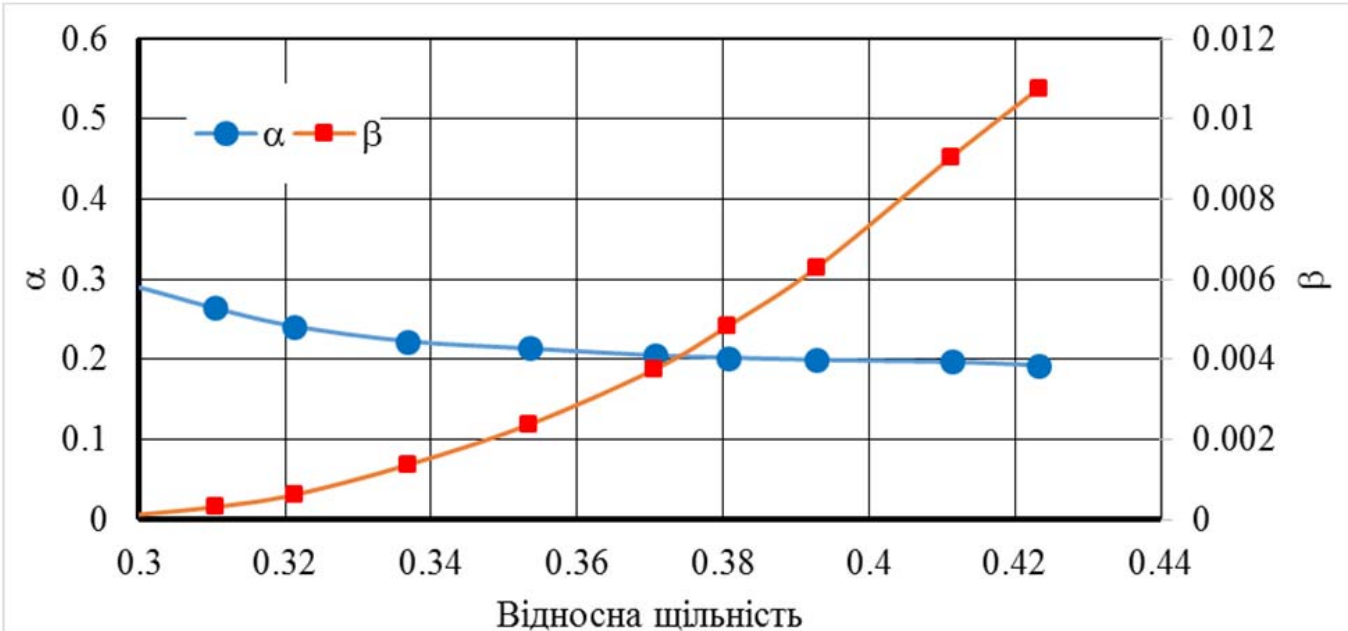

Рис. 8. Розподіл коефіцієнтів $\alpha$ і $\beta$ умови пластичності в залежності від відносної щільності при пресуванні титанового порошку в закритій матриці 
Шляхом аналізу залежності представленої на рис. 8 було встановлено, що коефіцієнти рівняння (8) можна прийняти рівними $\mathrm{a}=1,230, \mathrm{~m}=3,869$, при цьому коефіцієнт кореляції склав 0.867. Отримана кількісна оцінка показника степеню $\mathrm{n}$ склала $\mathrm{n}=5,485$ при коефіцієнті кореляції 0,895 , а значення $\sigma_{\mathrm{s}}$ дорівнювало $1152 \mathrm{H} / \mathrm{мм}^{2}$

Для більш точного опису отриманих залежностей, що необхідно при аналізі напружено-деформованого стану порошкового середовища в САЕ-системах, на основі статистичного аналізу були запропоновані наступні залежності:

$$
\alpha=\exp \left(\mathrm{a}+\mathrm{m} / \gamma^{2}\right) ; \beta=\mathrm{b} \gamma^{\mathrm{n}}
$$

Відповідно до цих залежностей коефіцієнти дорівнювали: $\mathrm{a}=-2.1 ; \mathrm{m}=0.074$ при коефіцієнті кореляції 0.993; b = 22.4, n = 8.831 при коефіцієнті кореляції 0.989 .

Співставлення відомої залежності (8) зі запропонованою (9) та експериментальною в графічному вигляді наведено на рис. 9.

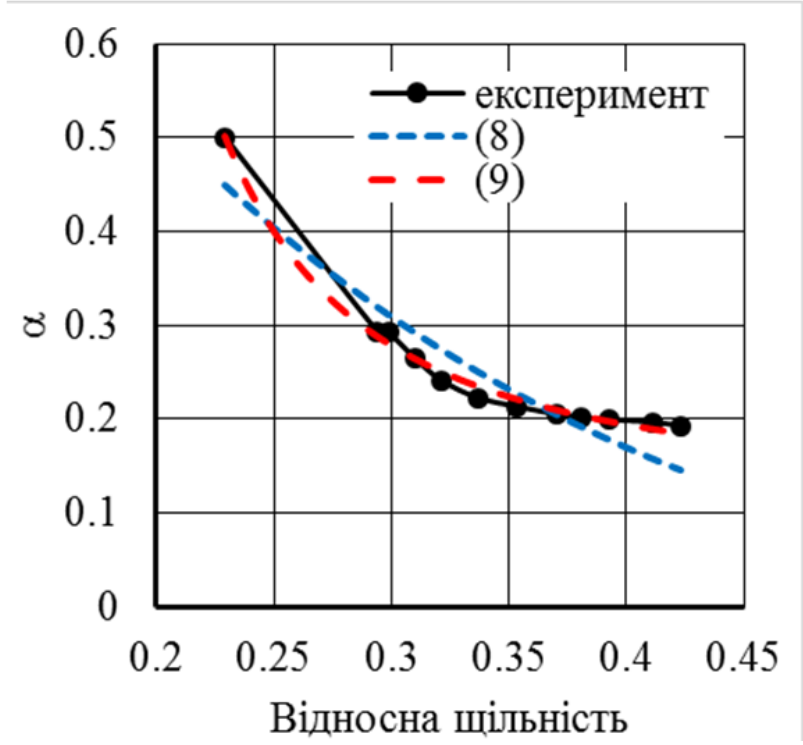

a

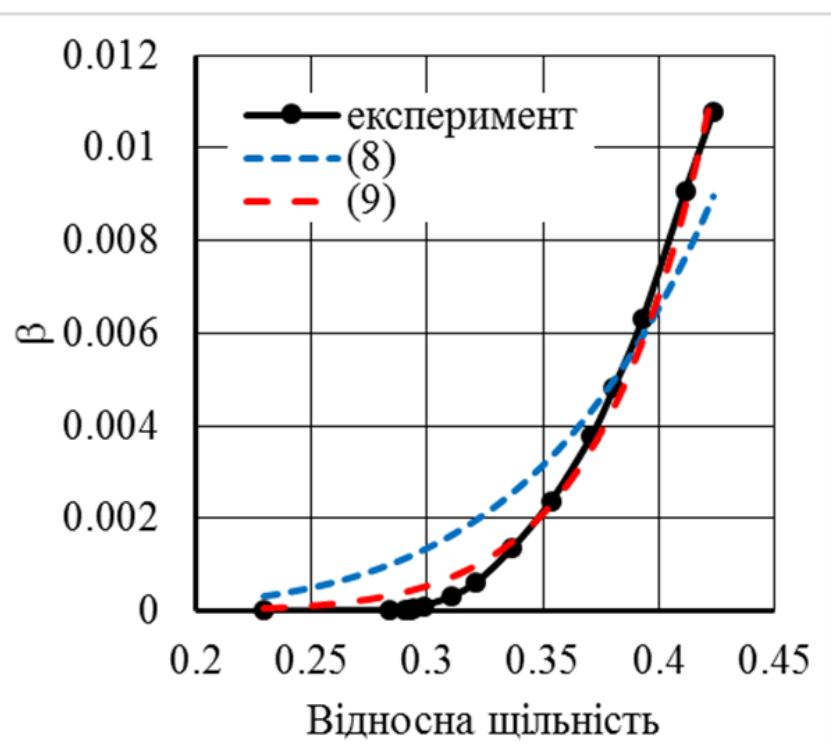

6

Рис. 9. Співставлення розподілів коефіцієнтів $\alpha$ (a) і $\beta$ (б) умови пластичності за формулами (8) і (9)

\section{ВИСНОВКИ}

В результаті проведення експериментальних досліджень з пресування порошкової композиції в закритій матриці отримані залежності осьових і радіальних напружень від щільності порошку. Дані залежності дозволили описати фізико-механічні властивості порошкових матеріалів на основі хрому. Для досліджуваної композиції визначені коефіцієнти, що входять в умову пластичності. Уточнено залежності для опису даних коефіцієнтів від відносної щільності, при цьому коефіцієнт кореляції склав близько 0,99, що вище на 10 ... 14 \% від відомих залежностей.

\section{СПИСОК ВИКОРИСТАНОЇ ЛІТЕРАТУРИ}

1. Faisal N.H., Ahmed R. Diametral compression test method to analyse relative surface stresses in thermally sprayed coated and uncoated circular disc specimens. Surface and Coatings Technology. 2019, 357, pp.497-514. DOI: https://doi.org/10.1016/j.surfcoat.2018.10.053.

2. Prikhodko I.Y., Dedik M.A., Gogaev K.A. et al. Finite-element optimization of the asymmetric rolling process for titanium powder. Powder Metallurgy and Metal Ceramics. 2016, 55, 1-2, pp. $12-18$. DOI: https://doi.org/10.1007/s11106-016-9774-3 
3. Keshavarz Sh., Khoei A.R., Molaeinia Z. Genetic algorithm-based numerical optimization of powder compaction process with temperature-dependent cap plasticity model. The International Journal of Advanced Manufacturing Technology. 2013, 64(5-8), pp. 1057-1072. DOI: https://doi.org/10.1007/s00170-012-4053-z.

4. Tseng H-C., Hung C., Huang C-C. An analysis of the formability of aluminum/copper clad metals with different thicknesses by the finite element method and experiment. The International Journal of Advanced Manufacturing Technology. 2010, 48(9-12), pp. 1029-1036. DOI: https://doi.org/10.1007/s00170-009-2446-4.

5. Wang X., Hua L., Han X., Wang X., et al. Numerical simulation and experimental study on geometry variations and process control method of vertical hot ring rolling. The International Journal of Advanced Manufacturing Technology. 2014, 73(1-4). pp. 389-398. DOI: https://doi.org/10.1007/s00170-014-5770-2.

6. Волкогон Г. М. , Дмитриев А. М., Добряков Е. П. и др. Прогрессивные технологические процессы штамповки деталей из порошков и оборудование. Под ред. Дмитриева А. М. Овчинникова А. Г. Машиностроение, 1991.320 с.

7. Березин И. М. Создание экспериментальной установки для гидростатического сжатия пористых материалов. Вестник ПНИПУ. Механика. 2013. 2. С. 37-51.

\section{REFERENCES}

1. Faisal N.H., Ahmed R. Diametral compression test method to analyse relative surface stresses in thermally sprayed coated and uncoated circular disc specimens. Surface and Coatings Technology. 2019, 357, pp. 497-514. DOI: https://doi.org/10.1016/j.surfcoat.2018.10.053.

2. Prikhodko I.Y., Dedik M.A., Gogaev K.A. et al. Finite-element optimization of the asymmetric rolling process for titanium powder. Powder Metallurgy and Metal Ceramics. 2016, 55, 1-2, pp. $12-18$. DOI: https://doi.org/10.1007/s11106-016-9774-3

3. Keshavarz Sh., Khoei A.R., Molaeinia Z. Genetic algorithm-based numerical optimization of powder compaction process with temperature-dependent cap plasticity model. The International Journal of Advanced Manufacturing Technology. 2013, 64(5-8), pp. 1057-1072. DOI: https://doi.org/10.1007/s00170-012-4053-z.

4. Tseng H-C., Hung C., Huang C-C. An analysis of the formability of aluminum/copper clad metals with different thicknesses by the finite element method and experiment. The International Journal of Advanced Manufacturing Technology. 2010, 48(9-12), pp. 1029-1036. DOI: https://doi.org/10.1007/s00170-009-2446-4.

5. Wang X., Hua L., Han X., Wang X., et al. Numerical simulation and experimental study on geometry variations and process control method of vertical hot ring rolling. The International Journal of Advanced Manufacturing Technology. 2014, 73(1-4). pp. 389-398. DOI: https://doi.org/10.1007/s00170-014-5770-2.

6. Volkogon G.M., Dmitriev A.M., Dobryakov E.P., et al. Progressive technological processes of stamping parts from powders and equipment. Eds. Dmitriev A.M. Ovchinnikov A.G. Moscow: Mechanical Engineering. 1991, 320 p. (in Russian).

7. Berezin I.M. Creation of an experimental setup for hydrostatic compression of porous materials. Bulletin of PNIPU. Mechanics. 2013, 2, pp. 37-51. (in Russian).

Грибков Е. П. - - д-р техн. наук, доц. ДДМА;

E-mail: amm@dgma.donetsk.ua;

Кассов В. Д. - - д-р техн. наук, проф. ДДМА;

E-mail:ptm@dgma.donetsk.ua;

Коваленко А. К. - асист. ДДМА;

E-mail: kit@dgma.donetsk.ua.

ДДМА - Донбаська державна машинобудівна академія, м. Краматорськ. 